\title{
Towards Viable Eco-friendly Matrices for Controlled Pesticide Delivery: Adsorptive Behaviour of Cow Dung Ash and Starch Towards Organophosphorus Pesticides
}

\author{
1,2 - Chinyere Emmanuella Okafor \\ Nnamdi Azikiwe University \\ 2 - Ikenna Onyido ( $\square$ ikennaonyido@gmail.com ) \\ Nnamdi Azikiwe University
}

\section{Research Article}

Keywords:

Posted Date: February 2nd, 2022

DOI: https://doi.org/10.21203/rs.3.rs-1258603/v1

License: (c) (i) This work is licensed under a Creative Commons Attribution 4.0 International License. Read Full License 


\title{
TOWARDS VIABLE ECO-FRIENDLY MATRICES FOR CONTROLLED PESTICIDE DELIVERY: ADSORPTIVE BEHAVIOUR OF COW DUNG ASH AND STARCH TOWARDS ORGANOPHOSPHORUS PESTICIDES
}

\author{
Chinyere Emmanuella Okafor ${ }^{1,2}$ \& Ikenna Onyido ${ }^{2 *}$ \\ ${ }^{1}$ Department of Science Education, Chukwuemeka Odumegwu Ojukwu University, \\ Uli, Anambra State, Nigeria \\ ${ }^{2}$ Department of Pure and Industrial Chemistry, Nnamdi Azikiwe University, Awka, Nigeria \\ Correspondence and requests for materials should be addressed to I.O. (email: \\ ikennaonyido@gmail.com and i.onyido@unizik.edu.ng)
}

\section{Abstract}

The work reported herein explores the viability of cow dung as a matrix for controlled pesticide delivery, by comparing its adsorptive characteristics towards two organophosphorus pesticides with those of starch, conventionally utilized in designing controlled pesticide delivery systems. Characterization of cow dung ash (CDA) was by Fourier transform infrared (FTIR) spectroscopy and powder X-ray diffraction (PXRD). Pesticide adsorption data on the surfaces correlate well with Langmuir and Freundlich isotherms, with the former isotherm giving a slightly better fit $\left(R^{2} \geq 0.90\right)$ than the latter $\left(R^{2}\right.$ $\geq 0.81$ ). Values of the adsorption parameters $K_{L}$ and $R_{L}$ indicate favourable pesticide adsorption on both surfaces. Desorption is the microscopic reverse of adsorption; both processes obey pseudo-second-order kinetics, implicating a mechanism in which adsorbate diffusion to the polymer surface and its transport into the polymer interior are important events. The isothermal and kinetic ratios $\frac{K_{L}^{C D A}}{K_{L}^{\text {Starch }}}=3.8$ and 4.0, $\frac{k_{2}^{C D A}}{k_{2}^{\text {Starch }}}=1.3$ and 0.6, and $\frac{k_{-2}^{C D A}}{k_{-2}^{\text {Starch }}}=5.2$ and 1.0 at $\mathrm{pH} 7$ and $27^{\circ} \mathrm{C}$, compare the adsorptive behaviour of diazinon and dichlorvos, respectively, on CDA and starch. These parameters are of the same order of magnitude, signalling that CDA is as potentially viable as starch for use as a matrix for pesticide-controlled delivery.

\section{Introduction}

Intensification of agricultural production in the drive towards food security as envisioned in the Sustainable Development Goals (SDGs) ${ }^{1}$ involves expansion of farmlands and increased use of farm inputs, such as fertilizers and pesticides. The use of pesticides is associated with environmental pollution, ${ }^{2}$ loss of biodiversity, ${ }^{3}$ damage to human health, ${ }^{4,5}$ etc. Sustainable 
resource management requires mitigation strategies that reduce environmental and human health risks associated with increased use of pesticides for intensified agricultural production. This has led to the search for approaches which deliver pesticides directly to targets, thereby minimizing the dissipation of the chemicals in the environment ${ }^{6}$ and the resulting ecotoxicity. A strategy which has caught our interest is the encapsulation of pesticides in eco-friendly matrices to obtain controlled release formulations (CRFs). This shields the pesticides from direct interactions with humans and the environment during their delivery and the length of their pesticidal action. ${ }^{7}$ First utilized in medicine to regulate drug delivery rates in patients, 8,9 this strategy is now a familiar approach in modern medicine. ${ }^{10}$

The matrices used for the preparation of controlled release formulations in this Age of Sustainable Development ${ }^{11}$ must be naturally occurring, biodegradable and biocompatible to scale the sustainability test. ${ }^{12}$ Ideally, such materials should be unfit for human consumption, so that the quest for environmental sustainability does not undermine food security by encroaching on the aggregate food supply and feedstock for agro-based industries, the kind of competition frequently encountered between biofuels and food security. ${ }^{13}$ Such matrices should also be inexpensive so that, ultimately, low-cost technologies derived from their use can be accessed by farmers, including resource-poor farmers who abound in developing countries. ${ }^{14}$ Biodegradable matrices so far encountered in controlled pesticide delivery systems are biopolymers such as the polysaccharides starch, cellulose, lignin, chitosan, dextran, agarose, alginates, (sometimes) proteinaceous materials such as gelatin and albumin, ${ }^{15}$ in addition to kaolin ${ }^{16,17}$ and kaolinite ${ }^{18}$ surfaces in a number of occasions.

Cow dung is a faecal waste freely available in rural farming communities, in animal markets and in formal and artisanal abattoirs. The bulk of available cow dung is largely regarded as waste in many communities. Cow dung has found use as soil amendments, ${ }^{19}$ as heating and cooking fuel, ${ }^{20}$ in biogas production, ${ }^{21}$ in mud-brick manufacture for housing, ${ }^{22}$ in compost manure, ${ }^{23}$ and in reducing bacterial and pathogenic diseases in traditional medicine. ${ }^{24,25}$ Some of these uses pose collateral threats to the health of users. To the best of our knowledge, this material has not been explored as a matrix for the formulation of controlled release pesticides. Its biodegradability, biocompatibility, and ready availability with little or no financial costs make it an ideal material for the development of low-cost 
technologies for increased food production in the context of environmental sustainability, with resource poor farmers who dominate the agricultural production space in developing countries as benefitting clienteles. Before interrogating its capabilities and behaviour as a controlled release matrix, it would be important to understand the basic adsorptive behaviour of cow dung towards commonly utilized pesticides, which is the focus of this paper.

We report on an exploratory study of the adsorption on and desorption from cow dung ash (see below) of two commonly used organophosphorus pesticides in developing countries, diazinon (1) and dichlorvors (2). Diazinon is a moderately hazardous Class II pesticide, ${ }^{26}$ while dichlorvos is extremely toxic to non-target organisms. ${ }^{27}$ The results obtained are compared with data also obtained in this study under the same experimental conditions for starch, a more conventional matrix, in order to preview the prospects of using CDA as a substitute for starch as a controlled delivery matrix for the two pesticides.<smiles>CCOP(=S)(OCC)Oc1cc(C)nc(C(C)C)n1</smiles><smiles>COP(=O)(OC)OC=C(Cl)Cl</smiles>

\section{Materials and Methods}

\section{Materials}

Diazinon, potassium phthalate, potassium dihydrogen sulphate, ninhydrin, ascorbic acid (Sigma-Aldrich), dichlorvos, sodium tetraborate decahydrate, sodium chloride (Merck), were all technical grade products, while corn starch, sodium hydroxide, glacial acetic acid and hydrochloric acid were all analytical grade chemicals obtained from the British Drug House, UK. These chemicals were used as supplied. Cow dung samples were collected from Kwata cattle market, Uli in Anambra State of Nigeria.

\section{Processing of cow dung for experimental use}

The cow dung sample utilized in the experiments was wet at the point of collection. It was dried at room temperature, ground in a mortar, and sieved to a particle size of $53 \mu \mathrm{m}$ with a standard sieve. The dry, sieved sample was ashed in a furnace at $550^{\circ} \mathrm{C}$ for an hour. The ashcoloured cow dung powder (CDA) obtained was stored in an airtight brown bottle which was protected from light. 


\section{Characterization of CDA}

\section{Fourier transform infrared spectroscopic analysis of CDA}

Fourier transform infrared (FTIR) spectra of pulverized samples of CDA were obtained using a ThermoFisher Nicolet 380 FT-IR operating in the range of $400-4000 \mathrm{~cm}^{-1}$ at a spectral resolution of $2 \mathrm{~cm}^{-1}$.

\section{X-Ray diffraction patterns of CDA}

CDA samples were first sieved onto the surface of a silicon disc pre-coated with petroleum jelly and then scanned on a ThermoFisher INEL Equinox $1000 \mathrm{X}$-ray diffractometer from 0$140^{\circ}(2 \theta)$.

\section{The adsorption-desorption equilibria of the pesticides on CDA and starch matrices}

Adsorption equilibrium studies involving the pesticides on CDA and starch matrices were studied by the batch equilibrium method. ${ }^{28,29}$ Aliquots of $10 \mathrm{ml}$ buffer solution $(\mathrm{pH}=4,7$ or 9) and $40 \mathrm{ml}$ of a solution of the pesticide of known concentration were introduced into Teflon bottles each of which contained $250 \mathrm{mg}$ of the adsorbent. The samples were vigorously agitated on a mechanical shaker for $2 \mathrm{hr}$ at $27^{\circ} \mathrm{C}$. The resulting suspension was subsequently centrifuged at 4,500 rpm for $10 \mathrm{~min}$. Five $\mathrm{ml}$ portions of the supernatant in each bottle was withdrawn for spectrophotometric determination of the active ingredient (a.i). Each experiment was duplicated. Pesticide solutions in the buffer medium in the absence of the adsorbent were treated similarly to serve as blanks.

Desorption of the pesticides from CDA and starch surfaces was measured at $\mathrm{pH} 7$ and $27^{\circ} \mathrm{C}$. Measurements were commenced immediately after adsorption equilibrium was attained. The adsorbent/adsorbate ratio was kept the same as in the adsorption measurements described above. Five $\mathrm{ml}$ of the supernatant was withdrawn for spectrophotometric analysis. This volume was replaced with $5 \mathrm{ml}$ of the buffer solution in order to maintain the sink conditions.

\section{Kinetics of pesticide adsorption on CDA and starch}

For each kinetics experiment, $250 \mathrm{mg}$ of the adsorbent (CDA or starch) was weighed into capped bottles, followed by the addition of $10 \mathrm{ml}$ buffer solution of $\mathrm{pH} 7$ and $40 \mathrm{ml}$ of the solution of the pesticide maintained at $27^{\circ} \mathrm{C}$. The capped bottles were placed on a mechanical shaker. At intervals of $0,10,20,40$, and 80 mins, a vial was taken and centrifuged at 4,500 
$\mathrm{rpm}$. Five $\mathrm{ml}$ of the supernatant solution was filtered through $0.2 \mu \mathrm{m}$ syringe filters; its concentration was then determined spectrophotometrically.

\section{Kinetics of the desorption of the pesticides from CDA and starch surface into water}

Desorption kinetics studies which were undertaken at $\mathrm{pH} 7$ and $27^{\circ} \mathrm{C}$, commenced immediately after the kinetics of the adsorption. Ten $\mathrm{ml}$ of the buffer solution at $\mathrm{pH} 7$ was poured into capped bottles containing the pesticide and the matrix. The bottles were shaken and then centrifuged. Five $\mathrm{ml}$ of the supernatant were withdrawn at known time intervals for spectrophotometric determination of the a.i. concentration.

\section{Spectrophotometric determination of concentrations}

Solutions of diazinon have a well-defined $\lambda_{\max }$ at $264 \mathrm{~nm}$, the wavelength used to obtain the molar absorptivity, $\varepsilon$, which enabled the concentration of the pesticide to be known from the spectrophotometric experimental readings. Solutions of dichlorvos, on the other hand, had no well-defined $\lambda_{\max }$ in the range of $200-800 \mathrm{~nm}$. However, the reaction between the pesticide and ninhydrin is quantitative, giving a product which has a well-defined $\lambda_{\max }$ at 401 $\mathrm{nm}$. Changes in the absorbance of the product solutions were related to their concentrations once the molar absorptivity, $\varepsilon$, was known. A modification of the method used by Tzaskos et al. ${ }^{30}$ for the derivatization of glyphosate with ninhydrin was used to estimate experimental concentrations of dichlorvos. A mixture of a known weight of dichlorvos and excess ninhydrin reagent prepared by the method of Moore ${ }^{31}$ was immersed in boiling water for 30 min and cooled in an ice-bath. After attaining room temperature, the resulting solution was diluted serially and their absorbances measured at $401 \mathrm{~nm}$ to obtain the calibration curve which enabled the calculation of $\varepsilon$.

\section{Results and discussion}

\section{Molar absorptivity of diazinon and the ninhydrin derivative of dichlorvos}

The molar absorptivity, $\varepsilon$, of diazinon and the ninhydrin derivative of dichlorvos, was measured as $1.73 \times 10^{4}$ and $3.34 \times 10^{3} \mathrm{~L} \mathrm{~mol}^{-1} \mathrm{~cm}^{-1}$, respectively. These molar absorptivity values enabled the conversion of experimental absorbances to pesticide concentrations by the application of the Beer-Lambert law. 


\section{Fourier transform infrared (FTIR) spectra of CDA}

Cow dung consists of $c a .80 \%$ water and undigested residues of fodder, faeces, urine, lignin, cellulose, hemicelluloses, amino acid residues from crude proteins, soil residues, an assortment of minerals, such as $\mathrm{K}, \mathrm{S}, \mathrm{Fe}, \mathrm{Mg}, \mathrm{Ca}, \mathrm{Co}, \mathrm{Mn}$, etc. ${ }^{32,33}$ The relative proportion of these species in cow dung would conceivably depend on the habitat in which the cattle is reared. Consequently, absorptions due to the $\mathrm{O}-\mathrm{H}$ function in lignin and the celluloses, $\mathrm{C}-\mathrm{H}$ stretches which abound in carbohydrate derivatives, the amide function and the $\mathrm{N}-\mathrm{H}$ bond from metabolized proteins/amino acid residues, the $\mathrm{Si}-\mathrm{O}$ bond stretching in $\mathrm{SiO}_{2}$ from soils, among others, would be expected in an IR spectrum of cow dung.

The FTIR spectrum of CDA given in Fig. 1(A) has a broad band between 3700 and 3000 $\mathrm{cm}^{-1}$ which is centred at $3419 \mathrm{~cm}^{-1}$ due to the stretching vibration of the $\mathrm{O}-\mathrm{H}$ group, consistent with the assignment by Ciolacu et al. ${ }^{34}$ for this functional group in the celluloses and lignin, possibly overlapped with the N-H asymmetric vibration. ${ }^{35}$ The band at $2918 \mathrm{~cm}^{-1}$ is assigned to the $\mathrm{C}-\mathrm{H}$ vibration in cellulose and lignin, while the peak at $1638 \mathrm{~cm}^{-1}$ is attributed to the stretch of the carbonyl function in amide residues and in lignin. ${ }^{36}$ The absorption at 1541$1519 \mathrm{~cm}^{-1}$ is suggestive of the N-H vibration of amino acid residues. ${ }^{37}$ The band at $1420 \mathrm{~cm}^{-1}$ is characteristic of the $-\mathrm{CH}_{2}$ - deformation in lignin which is reinforced by the symmetric bending vibration of the same group in cellulose. ${ }^{34}$ The absorption bands in the region $1243-$ $1030 \mathrm{~cm}^{-1}$ are assigned to the $\mathrm{C}-\mathrm{O}-\mathrm{C}$ vibrations of the diverse ether linkages present in the celluloses and lignin and to the Si-O stretch from adventitious soil in the cow dung.

The FTIR spectrum of starch has been very well studied..$^{38-40}$ The principal absorptions in an FTIR spectrum of starch and their assignments shown in Table 1 are taken from the work of Kizil et al., ${ }^{38}$ for comparison with the major absorptions reported above for CDA. The commonalities between the two matrices, CDA and starch, in terms of vibrating and stretching bonds in Table 1, give us a qualitative insight into the main functional groups and molecular fragments utilized by both matrices in their adsorptive behaviour towards adsorbates. The absorptions for CDA recorded in Table 1 are in general agreement with the FTIR band assignments of cow dung by Kiyasudeen et al. ${ }^{41}$ 
(A)

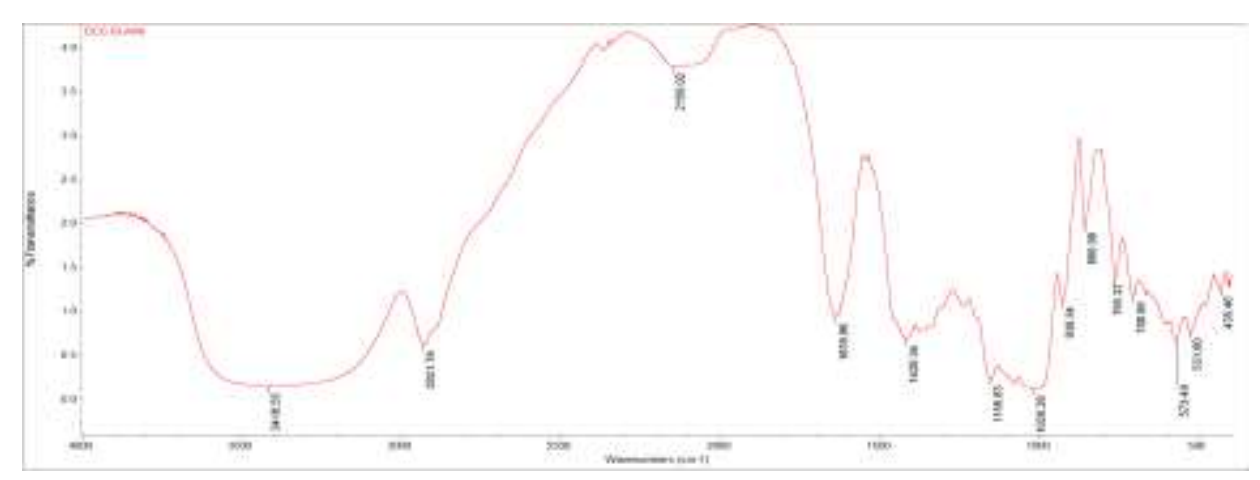

(B)

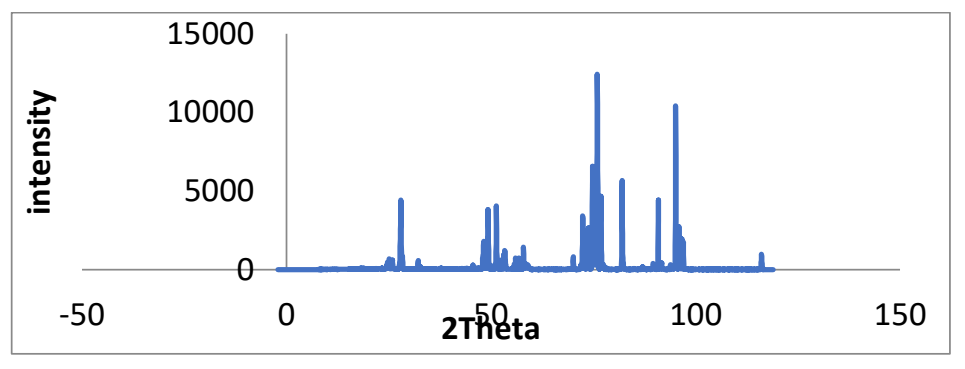

Figure 1. Spectroscopic characteristics of CDA: (A) FTIR spectrum of CDA used in this study. The sample was taken from CDA beads which contain alginate whose characteristic carboxylate - $\mathrm{COO}^{-}$ function absorbs in the $1420 \mathrm{~cm}^{-1}$ region; and (B) XRD patterns shown by CDA. The sample was taken from CDA beads which contain $\mathrm{Ca}^{2+}$ used for gelling the beads in our controlled release study (to be published) which is responsible for the peak at $2 \theta^{\circ}=27$.

Table 1. Band assignments for the FTIR spectra of $\mathrm{CDA}^{\mathrm{a}}$ and $\operatorname{starch}^{\mathrm{b}}$

\begin{tabular}{|c|c|c|c|}
\hline $\begin{array}{l}\text { Band in the FTIR } \\
\text { spectrum of } \operatorname{CDA}\left(\mathrm{cm}^{-1}\right)^{\mathrm{a}}\end{array}$ & Assignment & $\begin{array}{l}\text { Band in the FTIR } \\
\text { spectrum of } \operatorname{starch}\left(\mathrm{cm}^{-1}\right)^{b}\end{array}$ & Assignment \\
\hline $\begin{array}{l}3700-3000 \text { centred } \\
\text { at } 3419\end{array}$ & $\mathrm{O}-\mathrm{H}$ stretching & $3600-3000$ & $\mathrm{O}-\mathrm{H}$ stretching \\
\hline 2918 & $\mathrm{CH}_{2}$ deformation & $3000-2800$ & $\mathrm{CH}_{2}$ deformation \\
\hline 1638 & $\mathrm{C}=\mathrm{O}$ of amide residues & 1642 & $\mathrm{O}-\mathrm{H}$ from adsorbed water \\
\hline 1541-1519 & $\begin{array}{c}\mathrm{N}-\mathrm{H} \text { stretch of amino } \\
\text { acid residues }\end{array}$ & & \\
\hline \multirow[t]{2}{*}{1420} & $\begin{array}{l}\text { Lignin } \mathrm{CH}_{2} \text { deformation` } \\
\text { and cellulose } \mathrm{CH}_{2} \text { stretch }\end{array}$ & 1415 & $\mathrm{CH}_{2}$ bending, $\mathrm{C}-\mathrm{O}-\mathrm{O}$ stretch \\
\hline & & 1344 & $\mathrm{C}-\mathrm{O}-\mathrm{H}$ bending, $\mathrm{CH}_{2}$ twisting \\
\hline $1243-1030$ & $\begin{array}{l}\text { C-O-C vibrations of ether } \\
\text { linkages and Si-O stretch }\end{array}$ & $1242-1094$ & $\begin{array}{l}\mathrm{CH}_{2} \mathrm{OH}, \mathrm{C}-\mathrm{O}, \mathrm{C}-\mathrm{C} \text { stretching } \\
\text { and } \mathrm{C}-\mathrm{O}-\mathrm{H} \text { bending }\end{array}$ \\
\hline
\end{tabular}

${ }^{\mathrm{a}}$ Data obtained from this work. ${ }^{\mathrm{b}}$ Data taken from ref. 38. 


\section{Powder X-ray diffraction (PXRD) spectrum of CDA}

An X-ray diffraction study reveals the crystalline or amorphous nature of the sample under study, in this case that of cow dung. The X-ray diffractogram of a crystalline polymer sample yields sharp peaks while that of an amorphous sample gives diffuse peaks. The relatively sharp peaks obtained in the diffractogram in Fig. 1(B) gives the hint that the cow dung matrix utilized in this study is substantially crystalline. Since lignin is known to be largely amorphous and yields diffuse peaks, ${ }^{42,43}$ it is reasonable to infer from Fig. 1(B) that the cow dung matrix used in our study has significantly more amount of cellulose than lignin.

As noted earlier, cow dung would contain an assortment of organic and mineral compounds whose proportion would depend on the habitat in which the cattle are reared. For example, Avinash and Murugesan, ${ }^{42}$ in a chemometric analysis of cow dung ash, demonstrated that the following minerals showed XRD peaks at $2 \theta^{\circ}: \mathrm{SiO}_{2}$ from silica, 26.9; $\mathrm{Al}_{2} \mathrm{O}_{3}, 61.1 ; \mathrm{MgO}, 75.0 ; \mathrm{CaO}, 78.4 ; \mathrm{Fe}_{2} \mathrm{O}_{3}, 80.5$. These peaks are basically present in the PXRD spectrum of CDA blank beads shown in Fig. $1(B)$, in addition to the peaks at $2 \theta^{\circ}=24.8,26,27$, and several peaks at $2 \theta^{\circ}>80$. The peaks at $2 \theta^{\circ}=24.8$ and 26 are assigned to cellulose and silica, respectively, while the peak at $2 \theta^{\circ}=27$ is attributed to $\mathrm{Ca}$, part of which came from the gelling agent used in the formulation of the CDA beads. These assignments agree with the work of Li et al. ${ }^{44}$

\section{Adsorption-desorption equilibria of the pesticides on CDA and starch surfaces}

The capacity of a matrix to adsorb a pesticide and how readily (or reluctantly) the surface releases the adsorbed species are important factors, among many, that determine the ability of the matrix to deliver pesticides to specific sites in controlled quantities. Adsorptiondesorption data can provide useful information about the basic features of the adsorbing/desorbing system such as sorption mechanism, surface properties of the adsorbent and its affinity for the solute.

Adsorption equilibrium studies involving diazinon and dichlorvos on CDA and starch surface were undertaken by the batch equilibrium method ${ }^{45,46}$ The amount of the pesticide adsorbed, $q_{e}(\mathrm{mg} / \mathrm{g})$, was calculated on the basis of the principle of mass balance, according to Equation (1), where $C_{0}$ and $C_{e}=$ initial and final (i.e., equilibrium) concentrations $\left(\mathrm{mg} / \mathrm{dm}^{3}\right)$, respectively, of the pesticide in the aqueous phase; $v=$ volume of aqueous solution $\left(\mathrm{dm}^{3}\right)$; 
and $w=$ mass of adsorbent $(\mathrm{g})$. The experimental data for the adsorption of diazinon and dichlorvos on CDA and starch at $\mathrm{pH} 4,7$ and 9 at $27^{\circ} \mathrm{C}$ are assembled in Tables S1-S4 (Supporting Information); these are now modelled after the Langmuir and Freundlich isotherms to ascertain which of these two isotherms gives a better fit with our data.

$q_{e}=\left(C_{0}-C_{e}\right) \cdot \frac{v}{w}$

\section{The Langmuir adsorption isotherm}

The Langmuir isotherm, ${ }^{47}$ applicable to homogeneous surfaces, is given by Equation (2), where $K_{L}=$ the maximum adsorption $(\mathrm{mg} / \mathrm{g})$ to form a monolayer of the a.i., $C_{e}=$ equilibrium concentration of a.i. $\left(\mathrm{mg} / \mathrm{dm}^{3}\right)$ in the aqueous phase, $q_{e}=$ amount of a.i. adsorbed per unit mass of adsorbent, $b=$ Langmuir constant related to the affinity of the binding sites $(\mathrm{mg} / \mathrm{g})$ for sorbate molecules.

$\frac{C_{e}}{q_{e}}=\frac{C_{e}}{K_{L}}+\frac{1}{K_{L} b}$

Rearrangement of Equation (2) yields Equation (3); a plot of $1 / q_{e}$ versus $1 / C_{e}$ should yield a straight line, from which the Langmuir constants $K_{L}$ and $b$ can be extracted. The essence of the Langmuir isotherm is also captured by a dimensionless separation factor, $R_{L}$, defined by Equation (4). ${ }^{48,49}$ The magnitude of $R_{L}$ gives information about the favourability of the adsorption process or otherwise as follows: favourable if $0<R_{L}<1$; unfavourable $R_{L}>1$; linear if $R_{L}=1 ;$ and irreversible if $R_{L}=0$.

$$
\begin{aligned}
& \frac{1}{q_{e}}=\frac{1}{K_{L}}+\left(\frac{1}{K_{L} b}\right)\left(\frac{1}{C_{e}}\right) \\
& R_{L}=\frac{1}{1+b C_{0}}
\end{aligned}
$$

Data for the adsorption of diazinon and dichlorvos on CDA and starch surfaces are collected in Tables S1-S4 (Supplementary Information). Plots of $1 / q_{e}$ versus $1 / C_{e}$ at the three $\mathrm{pHs}$ studied for the adsorption of diazinon and dichlorvos on the two surfaces yield the Langmuir isotherms shown in Fig. 2, from which the Langmuir adsorption parameters assembled in Table 2 were extracted. 

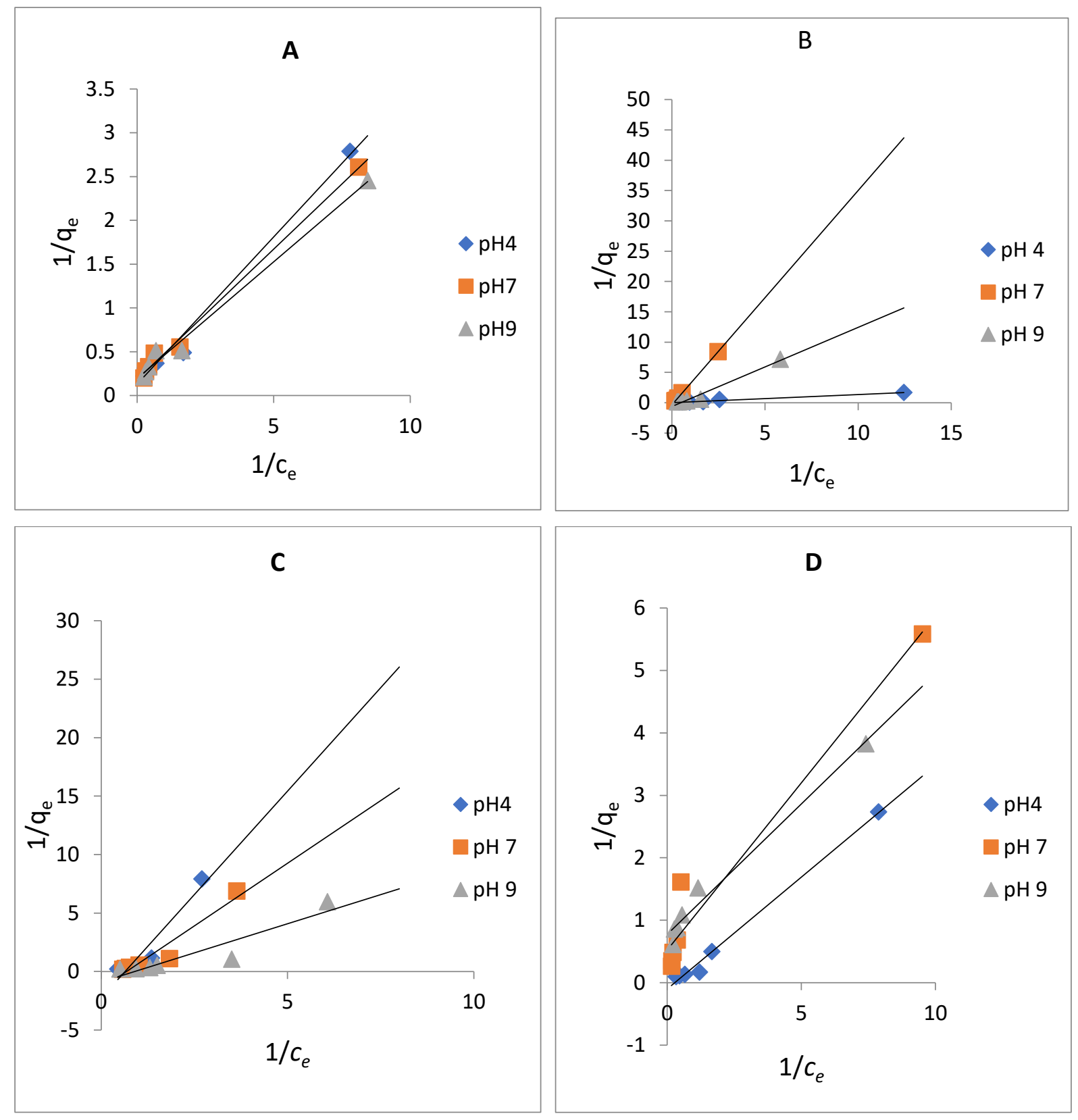

Figure 2. Langmuir isotherms at $27^{\circ} \mathrm{C}$ and pHs 4,7 and 9 for the adsorption of (A) diazinon and (B) dichlorvos on CDA and for the adsorption of (C) diazinon and (D) dichlorvos on starch.

The linearity of the plots in Fig. 2 for which $R^{2}$ values $\geq 0.9$ (see Table 2 ) shows that the Langmuir isotherm is applicable to the system under study which, mechanistically, means that the surface of the adsorbent is covered by a monolayer of the adsorbate. ${ }^{50}$ What is obvious from the data in Table 1 is that the adsorption capacity, $K_{L}$, for both pesticides follows the $\mathrm{pH}$ order of $4>7 \approx 9$ on CDA surface, and the $\mathrm{pH}$ order of $4>9>7$ on starch surface, which is to say that the adsorption of both adsorbates is more favourable in acidic solutions than in neutral and basic ones. 
Table 2. Langmuir parameters (derived from the plots in Figures 1 and 2) for the adsorption of diazinon and dichlorvos on CDA and starch surfaces at $27^{\circ} \mathrm{C}$ and different pHs.

\begin{tabular}{|c|c|c|c|c|c|c|c|}
\hline Matrix & Pesticide & pH & $\begin{array}{c}K_{L} \\
(\mathrm{mg} / \mathrm{g}) \\
\end{array}$ & $\begin{array}{c}b \\
\left(\mathrm{dm}^{3} / \mathrm{mg}\right) \\
\end{array}$ & $R_{L}$ & $R^{2}$ value & $\begin{array}{c}\Delta G_{a d s} \\
\left(\mathrm{~kJ} \mathrm{~mol}^{-1}\right)\end{array}$ \\
\hline \multirow[t]{6}{*}{$\overline{\mathrm{CDA}}$} & Diazinon & 4 & 2.76 & 0.12 & 0.31 & 0.988 & -2.5 \\
\hline & & 7 & 1.67 & 0.16 & 0.39 & 0.996 & -1.3 \\
\hline & & 9 & 1.67 & 0.18 & 0.33 & 0.993 & -1.3 \\
\hline & Dichlorvos & 4 & 5.41 & 0.03 & 0.76 & 0.982 & -4.2 \\
\hline & & 7 & 2.22 & 0.33 & 0.19 & 0.982 & -2.0 \\
\hline & & 9 & 2.88 & 0.10 & 0.15 & 0.999 & -2.6 \\
\hline \multirow[t]{6}{*}{ Starch } & Diazinon & 4 & 1.13 & 0.89 & 0.11 & 0.864 & -0.3 \\
\hline & & 7 & 0.44 & 0.64 & 0.08 & 0.922 & +2.0 \\
\hline & & 9 & 0.69 & 0.68 & 0.11 & 0.927 & +0.9 \\
\hline & Dichlorvos & 4 & 3.40 & 0.11 & 0.43 & 0.993 & -3.1 \\
\hline & & 7 & 0.56 & 0.76 & 0.09 & 0.980 & +1.4 \\
\hline & & 9 & 1.92 & 0.98 & 0.06 & 0.958 & -1.6 \\
\hline
\end{tabular}

We suggest that this observed effect of $\mathrm{pH}$ on $K_{L}$ is because proton coordination with the basic sites on the adsorbents and adsorbates in the acidic medium, which is absent in neutral and basic media, promotes hydrogen bonding and other non-covalent interactions, ${ }^{5}$ to enhance the adsorption of the solutes on the surfaces. This idea is consistent with the increase of the surface charge of the adsorbent and the degree of ionization of the adsorbates which have been advanced to explain the influence of $\mathrm{pH}$ on adsorbing systems. ${ }^{49,51}$ The ratio of the adsorptive capacity of the surface for dichlorvos, $K_{L}^{\text {dichl }}$, and for diazinon, $K_{L}^{\text {diaz }}$, i.e. $\frac{K_{L}^{\text {dichl }}}{K_{L}^{\text {diaz }}}=$ 2.0, 1.3, and 1.7 at $\mathrm{pH} \mathrm{4,} \mathrm{7,} \mathrm{and} \mathrm{9,} \mathrm{respectively,} \mathrm{for} \mathrm{CDA} \mathrm{surface} \mathrm{and} \mathrm{3.0,} \mathrm{1.3,} \mathrm{and} 2.8$ at $\mathrm{pH} 4$, 7, and 9, respectively, for starch shows that both surfaces have slightly higher capacities to adsorb dichlorvos than diazinon. The ratio of the surface adsorptive capacity of the two adsorbents $\frac{K_{L}^{C D A}}{K_{L}^{\text {Starch }}}=2.4,3.8$, and 2.4 for diazinon and 1.6, 4.0, and 1.5 for dichlorvos at $\mathrm{pH} 4$, 7, and 9, respectively, shows that CDA has slightly higher adsorptive capacities than starch for both pesticides at all the pHs investigated, although these values are of the same order of magnitude. It has been argued ${ }^{52,53}$ that $K_{L}$ does not represent a true thermodynamic function 
in adsorption processes. However chemical intuition suggests that $K_{L}$ is impliedly related to the true thermodynamic equilibrium constant, $K_{e q}^{a d s}$. In fact, $\mathrm{Liu}^{54}$ has shown that with uncharged solutes, $K_{L}$ approximates to the true equilibrium constant, $K_{\text {ads }}$. The solutes utilized in this study are uncharged organophosphorus esters in their standard states for which the statement $K_{L} \approx K_{e q}^{a d s}$ may be made, on the basis of Liu's assertion. This enables the free energy change for adsorption, $\Delta G_{a d s}$, to be obtained from the thermodynamic expression given in Equation (5). The $\Delta G_{a d s}$ values so obtained are included in Table 2.

$\Delta G_{a d s}=-R T \ln K_{L}$

$R_{L}$ values measured for the two adsorbates on the two surfaces at the different $\mathrm{pHs}$ are all < 1; this, from the definition of $R_{L}$ outlined above, ${ }^{48,49}$ is an indication that the adsorption of these species on the adsorbents is favourable, under the prevailing experimental conditions. The favourability of the adsorption process depicted by the magnitude of $R_{L}$ is confirmed by the values of $\Delta G_{a d s}$ obtained from the Langmuir $K_{L}$ values, on the assumption above, that $K_{L}$ $\approx K_{e q}^{a d s}$, except for the cases of the adsorption of diazinon on starch at the pHs 7 and 9, as well as the adsorption of dichlorvos at $\mathrm{pH} 7$, for which $\Delta G_{a d s}$ is positive but small. The small but negative $\Delta G_{a d s}$ values mostly observed accord with favourable adsorption of the physisorption type. ${ }^{55}$

\section{The Freundlich adsorption isotherm}

The expression for the Freundlich isotherm, ${ }^{56}$ applicable to heterogeneous surfaces, is given in Equation (6), where $K_{F}=$ the Freundlich adsorption capacity and $n=$ adsorption intensity. If $n>1$, the adsorption is deemed favourable. ${ }^{57}$ The linear form of Equation (6) is Equation (7), from which it is seen that a plot of $\log q_{e}$ versus $\log C_{e}$ should give a straight line with slope $=$ $1 / n$ and intercept $=\log K_{F}$. The data for the adsorption of diazinon and dichlorvos on CDA and starch surfaces in Tables S1-S4 (Supplementary Information), respectively, are treated graphically as discussed above to obtain the Freundlich isotherms for the two pesticides on the surfaces. These plots are shown in Fig. S1 (Supplementary Information).

$$
\begin{aligned}
& q_{e}=K_{F} C_{e}^{1 / n} \\
& \log q_{e}=\log K_{F}+\frac{1}{n} \log C_{e}
\end{aligned}
$$


Table 3. Freundlich parameters (derived from the plots in Figs. S1 and S2 (Supplementary Information) for the adsorption of diazinon and dichlorvos on CDA and starch surfaces at $27^{\circ} \mathrm{C}$ and different $\mathrm{pHs}$.

\begin{tabular}{|c|c|c|c|c|c|}
\hline Surface & Pesticide & $\mathrm{pH}$ & $\begin{array}{c}K_{F} \\
(\mathrm{mg} / \mathrm{g})(\mathrm{dm} 3 / \mathrm{mg})^{1 / \mathrm{n}}\end{array}$ & $\begin{array}{c}n_{F} \\
\left(\mathrm{dm}^{3} / \mathrm{mg}\right)\end{array}$ & $R^{2}$ value \\
\hline \multirow[t]{6}{*}{$\overline{\mathrm{CDA}}$} & Diazinon & 4 & 1.08 & 2.59 & 0.907 \\
\hline & & 7 & 1.08 & 2.38 & 0.959 \\
\hline & & 9 & 1.10 & 2.08 & 0.953 \\
\hline & Dichlorvos & 4 & 5.02 & 3.60 & 0.926 \\
\hline & & 7 & 2.89 & 0.79 & 0.984 \\
\hline & & 9 & 2.98 & 5.61 & 0.854 \\
\hline \multirow[t]{6}{*}{$\overline{\text { Starch }}$} & Diazinon & 4 & 1.18 & 3.82 & 0.843 \\
\hline & & 7 & 1.06 & 1.29 & 0.975 \\
\hline & & 9 & 1.03 & 1.00 & 0.941 \\
\hline & Dichlorvos & 4 & 1.30 & 1.21 & 0.987 \\
\hline & & 7 & 1.10 & 1.86 & 0.808 \\
\hline & & 9 & 1.18 & 1.39 & 0.993 \\
\hline
\end{tabular}

The Freundlich adsorption parameters resulting from these plots are collected in Table 3. As observed for the Langmuir adsorption isotherm above, the Freundlich adsorption capacity, $K_{F}$, is higher for dichlorvos than diazinon. However, while $K_{F}$ for dichlorvos is sensitive to medium $\mathrm{pH}$ as expected because it bears a site that could be protonated and follows the $\mathrm{pH}$ order of $4>7 \approx 9$, its value for diazinon is independent of $\mathrm{pH}$. The largely positive values of this parameter indicate that adsorption by the Freundlich mechanism is also favourable.

A close inspection of the adsorption parameters and $R^{2}$ values gathered in Tables 2 and 3, which were derived from the plots displayed in Figs. S1 (Supplementary Information) and 2 shows that, although the experimental data for the adsorption of both adsorbates on the two matrices follow both the Langmuir and Freundlich models, slightly better fits are obtained with the Langmuir model $\left(R^{2} \geq 0.90\right)$, when compared to its Freundlich counterpart $\left(R^{2} \geq 0.81\right)$ 


\section{Kinetics of the adsorption of diazinon and dichlorvos on CDA and starch surfaces}

In this section, data for the adsorption of the adsorbates on CDA and starch, collected as a function of time and shown in Tables S5 and S6 (Supplementary Information) are modelled after zero-, first- and second-order behaviour, in this order, to probe the kinetic order of reaction which best describes the adsorption process on both surfaces.

If the concentration of the solute (i.e., adsorbate) in solution is $c$ at time zero and the amount of solute adsorbed onto the surface is $b$ at time $t$, then the rate of adsorption for a zero-order process is given by Equation (8), ${ }^{58,59}$ where $k_{o}$ is the pseudo zero-order rate constant. According to Equation (8), a plot of $(c-b)$ against $t$ should give a straight line with slope $=k_{0}$. Such zero-order plots for the adsorption of diazinon and dichlorvos on CDA and starch surfaces are shown in Fig. S2 (Supplementary Information).

$(c-b)=c-k_{0} t$

$\ln (c-b)=\ln c+k_{1} t$

The rate equation for a first-order process is given by Equation (9), where $k_{1}$ is the pseudo first-order rate constant. According to this rate expression, a plot of $\ln (c-b)$ versus $t$ should give a straight line with slope $=k_{1}$. The kinetic plots for the adsorption of diazinon and dichlorvos on CDA and starch surfaces according to first-order behaviour are shown in Fig. S3 (Supplementary Information).

$\frac{t}{(c-b)}=\frac{1}{k_{2}}(c-b)^{2}+\frac{t}{(c-b)}$

Equation (10) is the rate expression for a second-order process, where $k_{2}$ is the pseudo second-order rate constant. A plot of $\frac{t}{(c-b)}$ against $t$ according to Equation (10) should give a straight line with slope $=\frac{1}{(c-b)}$ and intercept $=\frac{1}{k_{2}}(c-b)^{2}$. A combination of the slope and intercept would yield the pseudo second-order rate constant, $k_{2}$. The kinetic plots for the adsorption of both adsorbates on CDA and starch according to second-order behaviour are shown in Fig. 3. 

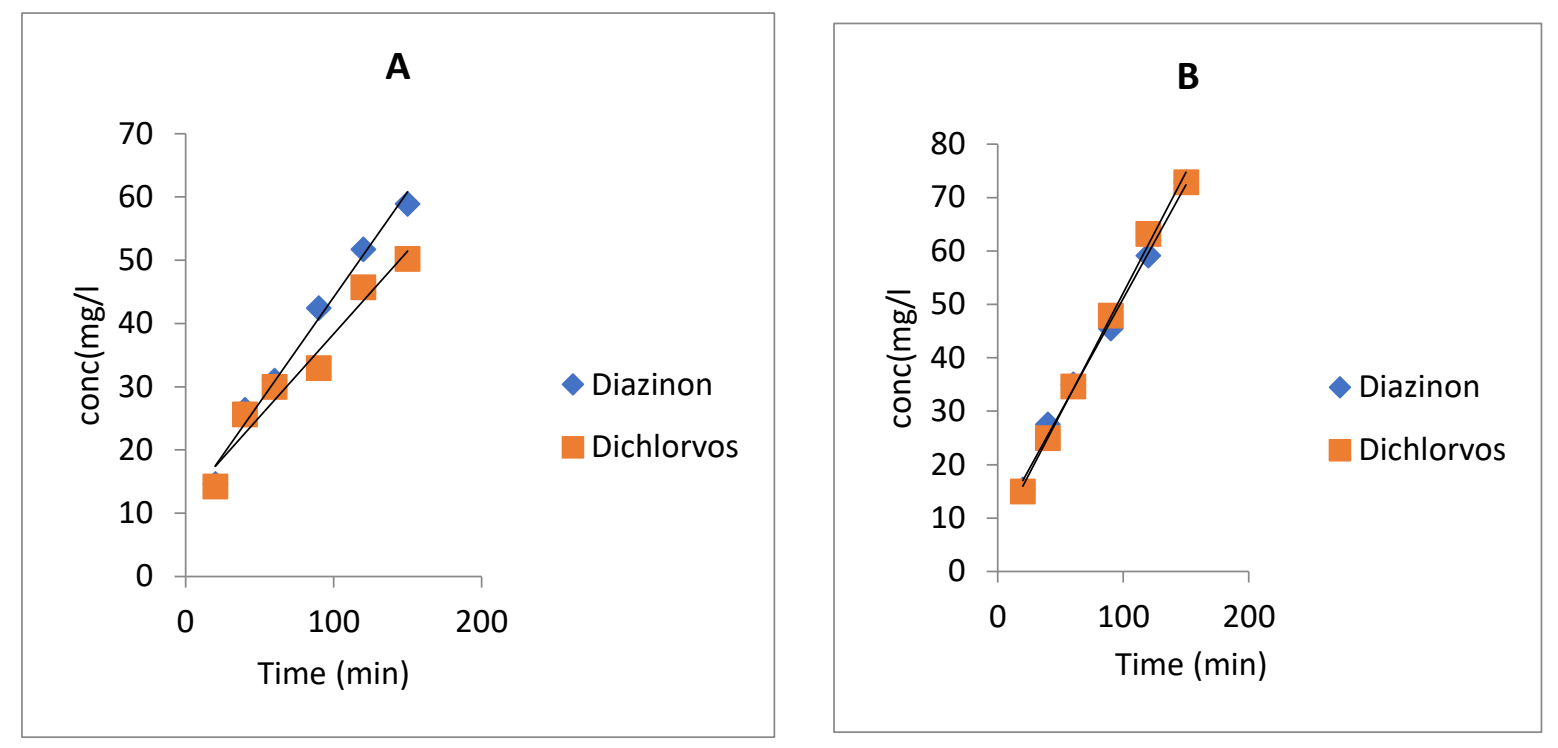

Figure 3. Second-order kinetic plots for (A) the adsorption of diazinon and dichlorvos on CDA surface and for (B) the adsorption of diazinon and dichlorvos on starch surface at $\mathrm{pH} 7$ and $27^{\circ} \mathrm{C}$.

Table 4. Rate constants and $R^{2}$ values obtained by modelling the adsorption of diazinon and dichlorvos on CDA and starch surfaces at $\mathrm{pH} 7$ and $27^{\circ} \mathrm{C}$.

\begin{tabular}{|c|c|c|c|c|}
\hline Surface & Pesticide & $\begin{array}{l}\text { Order of } \\
\text { reaction }\end{array}$ & Rate constant & $R^{2}$ value \\
\hline \multirow[t]{6}{*}{$\overline{\mathrm{CDA}}$} & Diazinon & Zero-order & $k_{0}=9.1 \times 10^{-3} \mathrm{mg} \mathrm{min}^{-1}$ & 0.962 \\
\hline & & First-order & $k_{1}=4.7 \times 10^{-3} \mathrm{~min}^{-1}$ & 0.928 \\
\hline & & Second-order & $k_{2}=3.3 \times 10^{-1} \mathrm{~g} \mathrm{mg}^{-1} \mathrm{~min}^{-1}$ & 0.985 \\
\hline & Dichlorvos & Zero-order & $k_{0}=4.0 \times 10^{-2} \mathrm{mg} \mathrm{min}^{-1}$ & 0.888 \\
\hline & & First-order & $k_{1}=1.9 \times 10^{-3} \mathrm{~min}^{-1}$ & 0.792 \\
\hline & & Second-order & $k_{2}=2.6 \times 10^{-1} \mathrm{~g} \mathrm{mg}^{-1} \mathrm{~min}^{-1}$ & 0.970 \\
\hline \multirow[t]{6}{*}{ Starch } & Diazinon & Zero-order & $k_{0}=6.0 \times 10^{-3} \mathrm{mg} \mathrm{min}^{-1}$ & 0.925 \\
\hline & & First-order & $k_{1}=4.0 \times 10^{-3} \mathrm{~min}^{-1}$ & 0.899 \\
\hline & & Second-order & $k_{2}=4.6 \times 10^{-2} \mathrm{~g} \mathrm{mg}^{-1} \mathrm{~min}^{-1}$ & 0.987 \\
\hline & Dichlorvos & Zero-order & $k_{0}=5.0 \times 10^{-3} \mathrm{mg} \mathrm{min}^{-1}$ & 0.888 \\
\hline & & First-order & $k_{1}=3.0 \times 10^{-3} \mathrm{~min}^{-1}$ & 0.855 \\
\hline & & Second-order & $k_{2}=7.5 \times 10^{-2} \mathrm{~g} \mathrm{mg}^{-1} \mathrm{~min}^{-1}$ & 0.996 \\
\hline
\end{tabular}

The rate constants and $R^{2}$ values derived from the kinetic plots in Figs. S2, S3 (Supplementary Information) and 4 according to pseudo zero-, pseudo first-, and pseudo second-order adsorption behaviour, respectively, of the two pesticides on CDA and starch, are summarized 
in Table 4. It is seen that $R^{2}$ values derived from the relevant plots are closest to unity for the second-order behaviour of dichlorvos adsorption, which suggests that the second-order adsorption kinetics is applicable to this pesticide on both CDA and starch surfaces.

The situation with the adsorption of diazinon on both surfaces is not so clear-cut: $R^{2}$ values are all $\geq 0.9$, with the plot for pseudo second-order behaviour being closest to unity. Literature reports on the kinetic behaviour of both adsorbates show that both pesticides are adsorbed by second-order kinetics on a variety of surfaces. For example, the adsorption of diazinon on surfaces as diverse as acid-activated bentonite ${ }^{60}$, surfactant-modified montmorillonites, ${ }^{61}$ a magnetic composite of clay/graphene oxide/ $\mathrm{Fe}_{3} \mathrm{O}_{4},{ }^{62}$ and $\mathrm{NH}_{4} \mathrm{Cl}$ induced activated carbon ${ }^{63}$ all proceed as pseudo second-order processes. Similarly, the adsorption of dichlorvos on coconut fibre biochar, ${ }^{64}$ on soil surfaces ${ }^{65}$ and on polyethyleneimine-modified fibres ${ }^{66}$ are all second-order processes. The data in Table 3 show that both diazinon and dichlorvos are adsorbed at comparable rates on CDA and starch, the ratio of the second-order rate constant for the adsorption of dichlorvos, $k_{2}^{\text {dichl }}$, and diazinon, $k_{2}^{\text {diaz }}$, i.e., $\frac{k_{2}^{\text {dichl }}}{k_{2}^{\text {diaz }}}$ being merely 0.8 and 1.6 for CDA and starch, respectively. Since the ratio $\frac{K_{L}^{\text {dichl }}}{K_{L}^{\text {diaz }}}=1.3$ (see Table 2) for the adsorption of these pesticides on both surfaces, it then appears that these two surfaces, CDA and starch, do not differ substantially in their thermodynamic and kinetic responses towards these adsorbents.

\section{Kinetics of the desorption of the pesticides from CDA and starch surfaces into water}

The release of the pesticides from CDA and starch surfaces into water was studied at $\mathrm{pH} 7$ using the decanting method described by Cruz-Guzman et al. ${ }^{29}$ The experimental data obtained for the desorption of diazinon and dichlorvos from CDA and starch surfaces are assembled in Tables S7 and S8 (Supplementary Information), respectively. The data were modelled after pseudo zero-, pseudo first-, and pseudo second-order behaviour, using Equations (8)-(10), as was done for adsorption kinetics. 

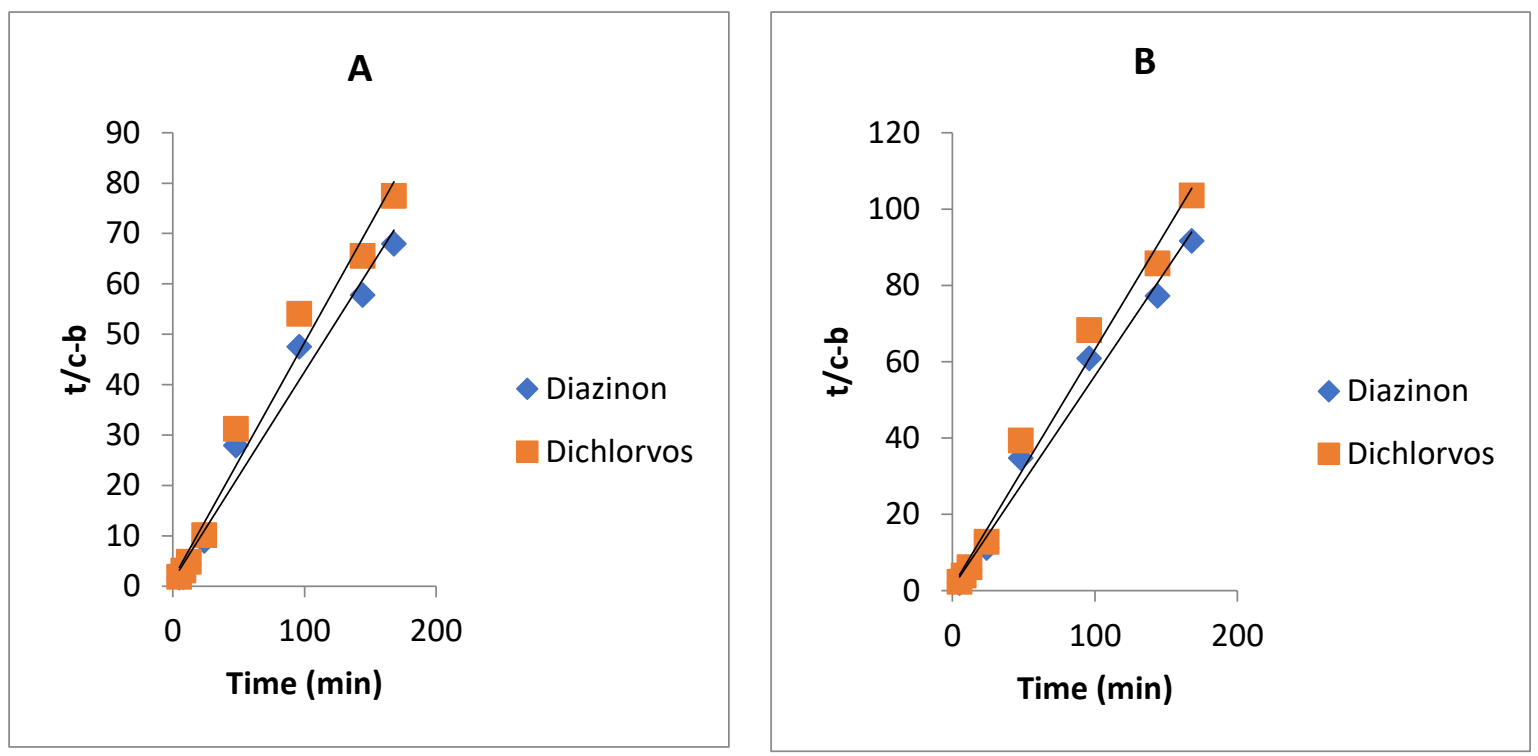

Figure 4. Second-order kinetic plots for the desorption of diazinon and dichlorvos from (A) CDA surface and (B) from starch surface into water at $\mathrm{pH} 7$ and $27^{\circ} \mathrm{C}$.

Table 5. Rate constants and $R^{2}$ values obtained by modelling the desorption of diazinon and dichlorvos from the CDA and starch surfaces into water at $\mathrm{pH} 7$ and $27^{\circ} \mathrm{C}$.

\begin{tabular}{|c|c|c|c|c|}
\hline$\overline{\text { Surface }}$ & Pesticide & $\begin{array}{l}\text { Order of } \\
\text { reaction }\end{array}$ & Rate constant & $R^{2}$ value \\
\hline \multirow[t]{6}{*}{$\overline{\mathrm{CDA}}$} & Diazinon & Zero-order & $k_{-0}=3.0 \times 10^{-3} \mathrm{mg} \mathrm{min}^{-1}$ & 0.763 \\
\hline & & First-order & $k_{-1}=1.0 \times 10^{-3} \mathrm{~min}^{-1}$ & 0.760 \\
\hline & & Second-order & $k_{-2}=1.1 \times 10^{-1} \mathrm{~g} \mathrm{mg}^{-1} \mathrm{~min}^{-1}$ & 0.973 \\
\hline & Dichlorvos & Zero-order & $k_{-0}=3.0 \times 10^{-3} \mathrm{mg} \mathrm{min}^{-1}$ & 0.818 \\
\hline & & First-order & $k_{-1}=1.0 \times 10^{-3} \mathrm{~min}^{-1}$ & 0.851 \\
\hline & & Second-order & $k_{-2}=2.3 \times 10^{-1} \mathrm{~g} \mathrm{mg}^{-1} \mathrm{~min}^{-1}$ & 0.998 \\
\hline \multirow[t]{6}{*}{ Starch } & Diazinon & Zero-order & $k_{-0}=4.0 \times 10^{-3} \mathrm{mg} \mathrm{min}^{-1}$ & 0.711 \\
\hline & & First-order & $k_{-1}=1.9 \times 10^{-3} \mathrm{~min}^{-1}$ & 0.767 \\
\hline & & Second-order & $k_{-2}=2.1 \times 10^{-1} \mathrm{~g} \mathrm{mg}^{-1} \mathrm{~min}^{-1}$ & 0.998 \\
\hline & Dichlorvos & Zero-order & $k_{-0}=3.0 \times 10^{-3} \mathrm{mg} \mathrm{min}^{-1}$ & 0.638 \\
\hline & & First-order & $k_{-1}=2.0 \times 10^{-3} \mathrm{~min}^{-1}$ & 0.712 \\
\hline & & Second-order & $k_{-2}=2.2 \times 10^{-1} \mathrm{~g} \mathrm{mg}^{-1} \mathrm{~min}^{-1}$ & 0.985 \\
\hline
\end{tabular}

The plots for zero-order and first-order desorption are shown in Figs. S4 and S5 (Supplementary Information), respectively, while those for second-order behaviour of both 
pesticides on CDA and starch surfaces are shown in Fig. 4. The rate constants and $R^{2}$ values extracted from these plots are displayed in Table 5.

It is clear from the $R^{2}$ values in Table 5, obtained from the plots in Figures S4, S5 (Supplementary Information) and 4, that the desorption kinetic data give the best fit for the two pesticides when modelled according to pseudo second-order behaviour on both surfaces. The ratio $\frac{k_{-2}^{\text {dichl }}}{k_{-2}^{\text {dioz }}}=2$ and 1 for CDA and starch, respectively, shows that dichlorvos desorbs from CDA surface twice as fast as diazinon, whilst both pesticides desorb from starch at similar rates. On the other hand, the ratio $\frac{k_{-2}^{C D A}}{k_{-2}^{\text {starch }}}=0.5$ and 1 for diazinon and dichlorvos, respectively, shows that there is just a 2 -fold difference in the desorption rates of both pesticides on going from CDA to starch. In other words, the second-order rate constants for the desorption of the two pesticides from the two surfaces are all of the same order of magnitude.

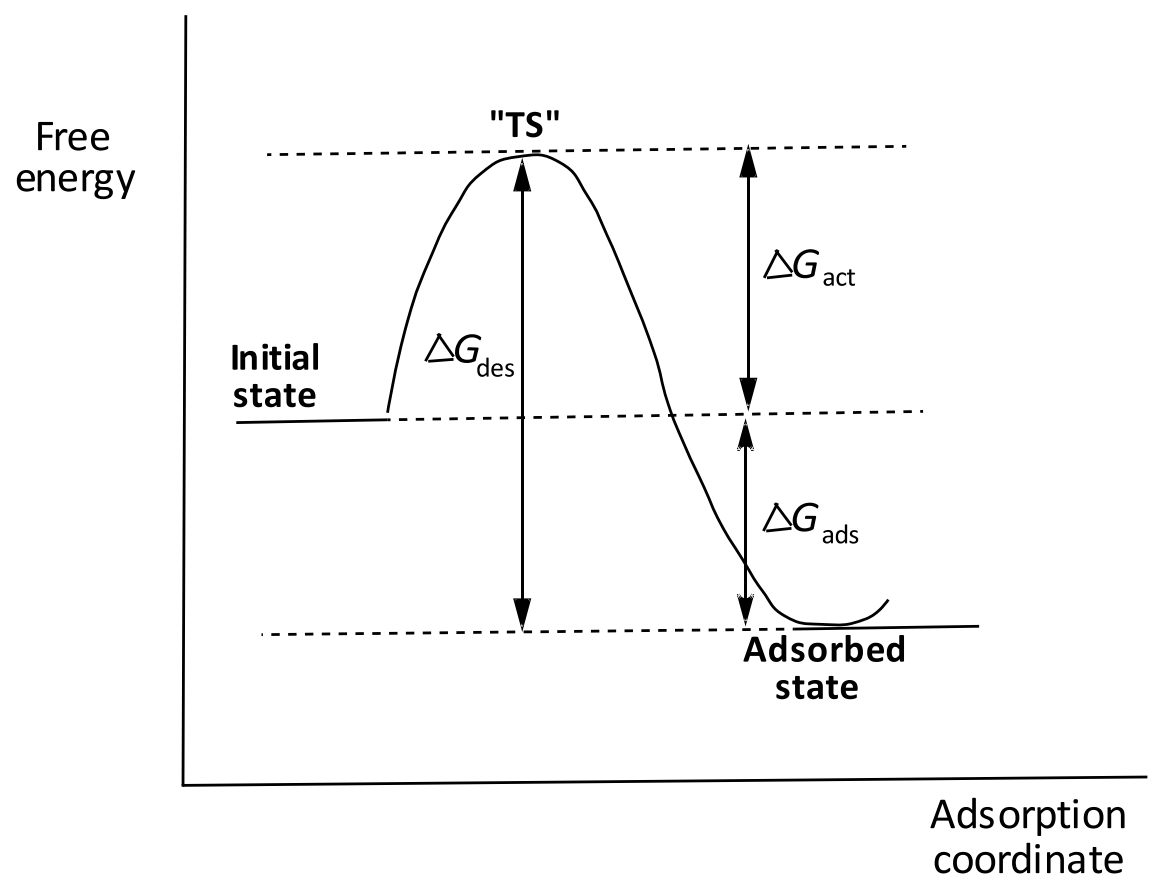

Figure 5: A two-dimensional free energy diagram in which an adsorption process is treated as a chemical reaction, showing the energy barriers for adsorption and desorption with a hypothetical transition state "TS". Desorption is seen as the microscopic reverse of adsorption.

Our kinetic data show that both the forward and reverse directions in the adsorption of the two pesticides follow second-order kinetics. The reverse process is therefore the microscopic reverse ${ }^{67-69}$ of the forward process, as illustrated in the free energy profile in Fig. 5, adapted 
from the paper by Hubbe et al. ${ }^{70}$ In Fig. 5, the free energy change for desorption, $\Delta G_{d e s}$, is a composite term which is related to the free energy change for adsorption, $\Delta G_{a d s}$, according to Equation (11), where $\Delta G_{a c t}$ is the free energy change of "activation," which could be regarded as the energy required to prepare the vacant site on the polymer for adsorption. The microscopic reverse of this process of "activation" as desorption takes place would entail the energy given out as the polymer surface returns to normality. These free energy terms are the energies required to overcome the barriers associated with adsorption, desorption, and "activation". Consequently, the quantities, $k_{a d s}, k_{d e s}$, and $k_{a c t}$, being the rate constants associated with overcoming the barriers to adsorption, desorption, and "activation," are related to $\Delta G_{a d s}, \Delta G_{a d s}$, and $\Delta G_{a d s}$, respectively, according to the generalized Eyring expression $^{67,68}$ in Equation (12), in which $k_{i}=$ a rate constant, $\Delta G_{i}=$ free energy change associated with $k_{i}, k=$ the Boltzmann constant, $h=$ the Planck constant, and $T=$ absolute temperature. It is a fairly settled issue that adsorption and desorption are related by microscopic reversibility. ${ }^{71,72}$ Fang et al., ${ }^{73}$ for example, have shown that the principle of microscopic reversibility is fulfilled by the rate constants for adsorption and desorption of proteins on cellulosic surfaces.

$\Delta G_{\text {des }}=\Delta G_{a d s}+\Delta G_{a c t}$

$k_{i}=\frac{k T}{h} e^{-\left(\Delta G_{i} / R T\right)}$

The second-order behaviour of the forward (adsorption) and reverse (desorption) processes as observed in this study could be interpreted to mean that the diffusion of the adsorbate from the bulk solution to the polymer surface or the transport of the particle into the interior of the polymers, or both, are mechanistically important events. ${ }^{74,75}$ The scope of the data does not enable the determination of which of these two processes is rate-limiting or, in fact, whether both steps are partially rate-limiting. The important finding from the kinetics herein reported is the comparable behaviour of the two surfaces, CDA and starch, towards the adsorption and desorption of the two pesticides.

\section{Conclusions}

The FTIR spectrum of CDA shows that there are functional groups and molecular fragments in this matrix which are also found in starch. The XRD spectrum informs that the matrix CDA is substantially crystalline. The adsorption of diazinon and dichlorvos, two organophosphorus pesticides widely used in tropical agriculture, on the two polymeric surfaces, CDA and starch, 
follow both the Langmuir and Freundlich adsorption models, with the Langmuir isotherm giving slightly better fits $\left(R^{2} \geq 0.90\right)$ than its Freundlich counterpart $\left(R^{2} \geq 0.81\right)$. The positive values of the Langmuir parameters $K_{L}$ and $R_{L}$ indicate that the adsorption of the pesticides on the two surfaces is favourable, while the range of the $\Delta G_{a d s}$ values evaluated from the Langmuir $K_{L}$ values, points to physisorption as the adsorption type. Data for the forward (adsorption) and reverse (desorption) processes are best modelled by second-order kinetics. This kinetic form in the forward and reverse directions accord with the principle of microscopic reversibility. Our isothermal and kinetics results show that CDA, a waste material that is readily available at no cost, yields adsorption and kinetic parameters which are of the same order of magnitude as those of starch. These results suggest that CDA is potentially viable for deployment as a matrix for the formulation of low-cost controlled pesticide release devices and could serve the same purpose as and therefore be a substitute for starch in this domain, as an example of sustainable and beneficial bioresource utilization.

\section{References}

1. Sustainable development goals: take action for the sustainable development goals. www.un.org/sustainabledevelopment/sustainable-development-goals/(2020).

2. Khan, M.J., Zia, M.F. \& Quasim, M. Use of pesticides and their role in environmental pollution. World Acad. Sci. Eng. Technol. 4, 12-25 (2010).

3. Hoshi, N. Adverse effects of pesticides on regional biodiversity and their mechanisms. In: Risks and regulation of new technologies (eds. Matsuda, T., Wolff, J. \& Yanagawa, T.) 235-247 (Springer, 2021).

4. Céspedes, F.F., Sánchez, M.V., Pérez García, S. \& Fernández Pérez, M. Modifying sorbents in controlled release formulations to prevent herbicides pollution. Chemosphere, 69, 785-794 (2007).

5. Akakuru O.U. \& Onyido, I. Controlled release formulations of 2,4dichlorophenoxyacetic acid with eco-friendly matrices for agricultural and environmental sustainability. Macromol. Res. 28, 40-53 (2021).

6. Farha, W., Abd El-Aty, A.M., Rahman, M.M., Shin, H.-C. \& Shim, J.-H. An overview on common aspects influencing the dissipation patterns of pesticides: a review. Environ. Monit. Assess. 188, 693 (2016). 
7. Li, N., Sun, C., Jiang, J., Wang, A., Wang, C., Shen, Y. Huang, B., An, C., Cui, B., Zhao, X., Wang, C., Gao, F., Zhan, S., Guo, L., Zeng, Z., Zhang, L., Cui, H. \& Wang, Y. Advances in controlled-release pesticide formulations with improved efficacy and targetability. J. Agric. Food Chem. 69(43), 12579-12597 (2021).

8. Yun, Y.H., Lee, B.K. \& Park, K. Controlled drug delivery: historical perspective for the next generation. J. Control. Release, 219, 2-7 (2015).

9. Lee, P.I. \& Li, J.-X. Evolution of oral controlled release dosage forms. In: Oral Controlled Release Formulation Design and Drug Delivery (eds. Wen, H. \& Park, K.) 21-31 (John Wiley \& Sons Inc., 2010).

10. Cai X.-J. \& Xu, Y.-Y. Nanomaterials in controlled drug release. Cytotechnol., 63, 319323 (2011).

11. J.D. Sachs, The Age of Sustainable Development (Columbia University Press: New York, 2015).

12. Letcher, T.M. \& Scott, J.L. Eds. Materials for a Sustainable Future www.rsc.org (RSC Publishing, 2012).

13. Koizumi, T. Biofuels and Food Security. Renew. Sust. Energ. Rev. 52, 829-841 (2015).

14. Lee, D.R. Agricultural sustainability and technology adoption: issues and policies for developing countries. Amer. J. Agric. Econ. 87, 1325-1334 (2005).

15. Roy, A., Singh, S.K., Bajpai, J. \& Bajpai, A.K. Controlled pesticide release from biodegradable polymers. Cent. Eur. J. Chem. 12(4), 453-469 (2014).

16. Singh, B., Sharma, D.K., Kumar, R. \& Gupta, A. Controlled release of the fungicide thiram from starch-alginate-clay based formulation. Appl. Clay Sci. 45, 76-82 (2009).

17. Hao, F., Liu, X., Yuan, H., Yan, X. \& Yang, D. Controlled-release granules for the delivery of pymetrozine to roots of transplanted rice seedlings with decreased phytotoxicity and enhanced control efficacy against paddy planthoppers. Pest Manag. Sci. https://doi.org/ 10.1002/ps.6696 (2021).

18. Kumar, J., Nisar, K., Shakil, N.A. \& Sharma, R. Residue and bio-efficacy evaluation of controlled release formulations of metribuzin against weeds in wheat. Bull. Environ. Contam. Toxicol. 85, 357-361 (2010).

19. Raj, A., Jhariya, M.K. \& Toppo, P. Cow dung for eco-friendly and sustainable productive farming. Environ. Sci. 3, 201-202 (2014). 
20. Roy, P.C., Datta, A. \& Chakraborty N. Assessment of cow dung as a supplementary fuel in a downdraft biomass gasifier. Renew. Energy, 35, 379-386 (2010).

21. Malolan, R., Jayaraman, R.S., Adithya, S., Arun, J., Gopinath, K. P., SundarRajan, P.S., Nasif, O., Kim, W. \& Govarthanan, M. Anaerobic digestate water for Chlorella pyrenoidosa cultivation and employed as co-substrate with cow dung and chicken manure for methane and hydrogen production: a closed loop approach. Chemosphere 266, 128963. https://doi.org/10.1016/..chemosphere.2020.128963 (2021).

22. Gupta, K.K., Aneja, K.R. \& Rana, D. Current status of cow dung as a bioresource for sustainable development. Bioresour. Bioprocess. 3, 28 (2016).

23. Pawlak K. \& Kolodziejczak, M. The role of agriculture in ensuring food security in developing countries: considerations in the context of the problem of sustainable food production. Sustainability 12, 5488 (2020).

24. Rajeswari, S., Poongothai, E. \& Hemalatha, N. Antimicrobial activities of cow dung extracts against human pathogens. Int. J. Curr. Pharm. Res. 8(4), 9-12 (2016).

25. Basak, A.B., Lee, M.W. \& Lee, T.S. Inhibitive activity of cow urine and cow dung against Sclerotinia sclerotorium of cucumber. Mycobiology 30, 175-179 (2018).

26. Azizi, A., Dargahi, A. \& Almasi, A. Biological removal of diazinon on a moving bed biofilm reactor - process optimization with central composite design. Toxin Rev. 40, 1242-1252 (2019).

27. J. Stanley \& G. Preetha, Pesticide Toxicity to Non-target Organisms (Springer: Switzerland AG, 2016).

28. Karthikeyan, G., Amblagan, \& Andal, M.N. Adsorption dynamics and equilibrium studies of Zn(II) onto chitosan. J. Chem. Sci. 116, 119-127 (2004).

29. Cruz-Guzmán, M., Celis, R., Hermosin, M.C., Koskinen, W.C. \& Cornejo, J. J. Agric. Food Chem. 53, 7502-7511 (2005).

30. Tzaskos, D.F., Marcovicz, C., Dias, N.M.P. \& Rosso, N.D. Development of sampling for quantification of glyphosate in natural waters. Ciênc. Agrotec., Lavras, 36, 399-405 (2012).

31. Moore, S. Amino acid analysis: aqueous dimethyl sulphoxide as solvent for the ninhydrin reaction. J. Biol. Chem. 243, 6281-6283 (1968). 
32. Maruga Raja, M.K.M., Manne, R. \& Devarajan, A. Benefits of cow dung - a human ignored gift. J. Nat. Remedies, 21 (2021). DOI: 10.18311/jnr/2021/26653.

33. Gupta, K.K., Aneja, K.R. \& Rana, D. Current status of cow dung as a bioresource for sustainable development. Bioresour. Bioprocess. 3: 28 (2016). DOI 10.1186/ s40643016-0105-9.

34. Ciolacu, D., Oprea, A.M., Anghel, N., Cazacu, G. \& Cazacu, M. New cellulose-lignin hydrogels and their application in controlled release of polyphenols. Mater. Sci. Eng. C 32, 452-463 (2012) and references therein.

35. Liu, W., Ye, Z., Liu, D. \& Wu, Z. Hydrogels derived from lignin with pH responsive and magnetic properties. Bioresources 13, 7281-7293 (2018).

36. Hergert, H.L. Infrared spectra of lignin and related compounds. II. Conifer lignin and related compounds. J. Org. Chem. 25, 405-413 (1960).

37. Venyaminov, S.Y \& Kalnin N.N. Quantitative IR spectrophotometry of peptide compounds in water solutions. I. Spectral parameters of amino acid residue absorption bands. Biopolymers https://doi.org/10.1002/bip.360301309 (1990).

38. Kizil, R., Irudayaraj, J. \& Seetharaman, K. Characterization of irradiated starches by using FT-Raman and FTIR spectroscopy. J. Agric. Food Chem. 50, 3912-3918 (2002).

39. Xu, Y.X., Kim, K.M., Hanna, M.A. \& Nag, D. Novel starch/chitosan blending membrane: antibacterial, permeable, and mechanical properties. Ind. Crops Prod. 21, 185-192 (2005).

40. Warren, F.J., Gidley, M.J. \& Flanagan, B.M. Infrared spectroscopy as a tool to characterize starch ordered structure - a joint FTIR-ATR, NMR, XRD and DSC study. Carbohydr. Polym. 139, 35-42 (2016).

41. Kiyasudeen, S.K., bin Ibrahim, M.H. \& Ismail, S.A. Characterization of fresh cattle wastes using proximate, microbial, and spectroscopic principles. American-Eurasian J. Agric. Environ. Sci. 15, 1700-1709 (2015).

42. Avinash, A. \& Murugesan, A. Chemometric analysis of cow dung ash as an adsorbent for purifying biodiesel from waste cooking oil. Sci. Rep. 7: 9526. DOI10.1038/s41598-

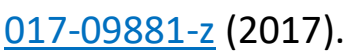


43. C. Cho, T. Aye, A. Khaing, and T. Kobayashi, Comparative study of cellulose hydrogels films prepared from variousbiomass wastes. Cellulose DOI: 10.5772/intechopen. $\underline{99215}$ (2021).

44. Li, R., Chen S. \& Li, X. Anaerobic co-digestion of kitchen waste and cattle manure for methane production, Energ. Sources, Part A 31, 1848-1856.

DOI: $10.1080 / 15567030802606038$ (2009).

45. Guo, M., Lin, Q., Xu, Z., Zhang, C., Zhao, X. \& Tang, T. Adsorption-desorption behaviour of endocrine-disrupting chemical quinestrol in soils. Sci. Rep. (2020). https://doi.org/ 10.1038/s41598-020-70300-x.

46. Onyido, I., Sha'ato, R. \& Nnamonu, L.A. Environmentally friendly formulations of trifluralin based on alginate modified starch. J. Environ. Protect. 3, 1085-1093 (2012).

47. Langmuir, I. The constitution and fundamental properties of solids and liquids. Part I. Solids. J. Am. Chem. Soc. 38, 2221-2295 (1916).

48. Hall, K.R., Eagleton, L.C., Acrivos, A. \& Vermeulen, T. Pore- and solid-diffusion kinetics in fixed-bed adsorption under constant-pattern conditions. Ind. Eng. Chem. Fundamen. 5, 212-223 (1966).

49. Hameed, B.H. \& Rahman, A.A. Removal of phenol from aqueous solutions by adsorption onto activated carbon prepared from biomass material. J. Hazard. Mater. $160,576-581$ (2008).

50. Al-Ghouti, M.A. \& Da'ana, D.A. Guidelines for the use and interpretation of adsorption isotherm models: A review. J. Hazard Mater. 393, 122383-122395 (2020).

51. Loganathan, P., Vigneswaran, S. \& Kandasamy, J. Enhanced removal of nitrate from water using surface modification of adsorbents - a review. J. Environ. Manage. 131, 363-374 (2013).

52. Lima, E.C., Hosseini-Bandegharaei, A., Moreno-Piraján, J.C. \& Anastopoulos, I. A critical review of the estimation of the thermodynamic parameters on adsorption equilibria. Wrong use of the equilibrium constant in the V'ant Hoff equation for the calculation of thermodynamic parameters of adsorption. J. Mol. Liq. 273, 425-434 (2019).

53. Pan, G. G. \& Liss, P.S. Metastable-equilibrium adsorption theory. I. Theoretical. J. Colloid Interface Sci. 201, 71-76 (1998).

54. Liu, Y. Is the free energy change of adsorption correctly calculated? J. Chem. Eng. Data. 54, 1981-1985 (2009). 
55. Bekçi, Z., Seki, Y. \& Cavas, L. Removal of malachite green by using an invasive marine alga Caulerpa racemosa var. cylindracea. J. Hazard. Mat. 161, 1454-1460 (2009).

56. Freundlich, H.M.F. Uber die adsorption in losungen. Zeitsch. Physik. Chem. 57, 385470 (1906).

57. McKay, G., Blair, H.S. \& Gardner, J.R. Adsorption of dyes on chitin. I. J. Appl. Polym. Sci. 27, 3043-3057 (1982).

58. Atkins, P. \& De Paula, J. Physical Chemistry. Chapter 21. (Oxford University Press: Oxford, 2010).

59. Onyido, I. A Primer for Kinetics and Mechanism for Chemistry and the Molecular Biosciences. Chapter 1. (University Press: Ibadan, Nigeria, 2018).

60. Ouznadji, Z.B., Sahmoune, M.N. \& Mezenner, Adsorptive removal of diazinon: kinetic and equilibrium study. N.Y. Desalin. Water Treat. 57, 1880-1889 (2016).

61. Hassani, A., Khataee, A., Karaca, S. \& Shirzad-Siboni, M. Surfactant-modified montmorillonite as a nanosized adsorbent for removal of an insecticide: kinetic and isotherm studies. Environ. Tech. 36, 3125-3135 (2015).

62. Sohrabi, N., Mohammadi, R., Ghassemzadeh, H.R. \& Heris, S.S.S. Equilibrium, kinetic and thermodynamic study of diazinon adsorption from water by clay/GO/ $/ \mathrm{e}_{3} \mathrm{O}_{4}$ : Modelling and optimization based on response surface methodology and artificial neural network. J. Mol. Liq. 328, 115384-115 (2021).

63. Moussavi, G., Hosseini, H. \& Alahabadi, A. The investigation of diazinon pesticide removal from contaminated water by adsorption onto $\mathrm{NH}_{4} \mathrm{Cl}$-induced activated carbon. Chem. Eng. J. 214, 172-179 (2013).

64. Bihn, Q.A. \& Kajitvichyanakul, P. Adsorption mechanism of dichlorvos on coconut fibre biochar: the significant dependence of $\mathrm{H}$-bonding and pore-filling mechanism. Water Sci. Technol. 79, 866-876 (2019).

65. Kaur, P. \& Sud, D. Adsorption kinetics, isotherms, and desorption of monocrotophos and dichlorvos on various Indian soils. Clean - Soil Air Water 39, 1060-1067 (2011).

66. Abdelhameed, R.M., El-Zawahry, M. \& Emam, H.E. Efficient removal of organophosphorus pesticides from wastewater using polyethyenimine-modified fabrics. Polymer 155, 225-34 (2018). 
67. Jencks, W.P. Catalysis in Chemistry and Enzymology. (Dover Publications, Inc.: New York, 1987).

68. Anslyn, E.V. \& Dougherty, D.A. Modern Physical Organic Chemistry. (University Science Books: Sausalito, CA., 2006).

69. Onyido, I. Catalysis, Structure and Reactivity in Chemistry and the Molecular Life Sciences. (University Press Plc.: Ibadan, Nigeria, 2018).

70. Hubbe, M.A., Azizian, S. \& Douven, S. Implications of apparent second-order adsorption kinetics onto cellulosic materials: a review. BioResources 14, 7582-7626 (2019).

71. Lilienkamp, G. \& Toennies, J.P. The observation of one-photon assisted selective desorption and adsorption of He atoms in defined vibrational levels on LiF (001) single crystal surface. J. Chem. Phys. 78, 5210 (1983).

72. Salvador, P. Semiconductors' photoelectrochemistry: a kinetic and thermodynamic analysis in the light of equilibrium and non-equilibrium models. J. Phys. Chem. B 105, 6128-6141 (2001).

73. Fang, F., Satulovsky, J. \& Szleifer, I. Kinetics of protein adsorption and desorption on surfaces with grafted polymers. Biophys. J. 89, 1516-1533 (2005).

74. Vasconcelos, P.N.M., Lima, W.S., Silva, M.L.P., Brito, A.L.F., Laborde, H.M. \& Rodrigues, M.G.F. Adsorption of zinc from aqueous solutions using modified Brazilian gray clay. Amer. J. Anal. Chem. 4. DOI:10.4236/ajac.2013.49065 (2013).

75. Ammar, N.E.B., Saied, T., Mejri, A., Hosni, F., Mnif, A. \& Hamzaoui, A.H. Study of agar proportions effect on a gamma ray synthesized hydrogel. J. Mat. Sci. Eng. A 3, 88-100 (2016).

\section{Author contributions}

I.O. conceived this research as part of the research themes in his group. C.E.O. performed all the experimental work under the supervision of I.O. C.E.O. wrote a portion of the first draft and produced the graphics for the manuscript. I.O. completed and revised the first draft to obtain the final version.

\section{Competing interests}

The authors have no competing interests to declare. 


\section{LEGEND FOR TABLES}

Table 1. Band assignments for the FTIR spectra of CDA and starch.

Table 2. Langmuir parameters (derived from the plots in Figs. 1 and 2) for the adsorption of diazinon and dichlorvos on CDA and starch surfaces at $27^{\circ} \mathrm{C}$ and different $\mathrm{pHs}$.

Table 3. Freundlich parameters (derived from the plots in Figs. S1 and S2 (Supplementary Information) for the adsorption of diazinon and dichlorvos on CDA and starch surfaces at $27^{\circ} \mathrm{C}$ and different $\mathrm{pHs}$.

Table 4. Rate constants and $R^{2}$ values obtained by modelling the adsorption of diazinon and dichlorvos on CDA and starch surfaces at $\mathrm{pH} 7$ and $27^{\circ} \mathrm{C}$.

Table 5. Rate constants and $R^{2}$ values obtained by modelling the desorption of diazinon and dichlorvos from the CDA and starch surfaces into water at $\mathrm{pH} 7$ and $27^{\circ} \mathrm{C}$.

\section{LEGEND FOR FIGURES}

Figure 1. Spectroscopic characteristics of CDA: (A) FTIR spectrum of CDA used in this study. The sample was taken from CDA beads which contain alginate whose characteristic carboxylate -COOfunction absorbs in the $1420 \mathrm{~cm}^{-1}$ region; and (B) XRD patterns shown by CDA. The sample was taken from CDA beads which contain $\mathrm{Ca}^{2+}$ used for gelling the beads in our controlled release study (to be published) which is responsible for the peak at $2 \theta^{\circ}=27$. 
Figure 2. Langmuir isotherms at $27^{\circ} \mathrm{C}$ and pHs 4,7 and 9 for the adsorption of (A) diazinon and (B) dichlorvos on CDA and for the adsorption of (C) diazinon and (D) dichlorvos on starch.

Figure 3. Second-order kinetic plots for (A) the adsorption of diazinon and dichlorvos on CDA surface and for $(\mathrm{B})$ the adsorption of diazinon and dichlorvos on starch surface at $\mathrm{pH} 7$ and $27^{\circ} \mathrm{C}$.

Figure 4. Second-order kinetic plots for the desorption of diazinon and dichlorvos from (A) CDA surface and (B) from starch surface into water at $\mathrm{pH} 7$ and $27^{\circ} \mathrm{C}$.

Figure 5: A two-dimensional free energy diagram in which an adsorption process is treated as a hypothetical chemical reaction, showing the energy barriers for "activation", adsorption and desorption with a hypothetical transition state "TS". Desorption is seen as the microscopic reverse of adsorption. 


\section{Supplementary Files}

This is a list of supplementary files associated with this preprint. Click to download.

- MANUSCRIPT1SUPPINFOFILEFINALA.docx 